\title{
MEMBANGUN BUSINESS MODEL: SEBUAH TELAAH KONSEPTUAL DAN PENGALAMAN PRAKTIS ${ }^{1}$
}

\author{
Achmad Sobirin \\ Fakultas Ekonomi Universitas Islam Indonesia \\ e-mail:asobirin@fe.uii.ac.id
}

\begin{abstract}
Business model is relatively a new term that emerged in 1990s together with the mushroom of e-business. Conceptually business model is therefore still in infancy. Despite this fact however it does matter (Magretta, 2002). Business model which is conceived as the logic of doing business, a construct, a mental model or a business paradigm, is considered a guide on how to do every day's business.

Based on the above mentioned understanding, this paper based on action research study, discusses the implemention of the concept of business model on change management using the case of Universitas Islam swasta. The result indicates that changing business model will inevitably change the organizational architecture and governance.
\end{abstract}

Keywords: business model, organizational architecture and governance.

\section{PENDAHULUAN}

Seorang pelaku bisnis yang memulai usaha barunya pasti mempunyai keyakinan bahwa Ia bisa menciptakan nilai tambah melalui kegiatan bisnis tersebut meski tidak jarang ia buta terhadap siapa calon konsumen dan apa keinginan mereka. Untuk mengatasi ketidaktahuan terhadap calon konstituen tidak jarang pula ia lantas mengandai-andai dan membuat asumsi tindakan dimulai dari menyusun business concept diikuti dengan business plan yang dianggap tepat dalam rangka untuk memenuhi kebutuhan calon konsumen. Jika asumsi pertama gagal, ia akan membuat asumsi tindakan lain sampai menemukan asumsi tindakan yang tepat yang benarbenar bisa menciptakan nilai tambah dan memenuhi keinginan para pelanggan. Saat itulah apa yang dilakukan pelaku bisnis tersebut telah berubah menjadi sebuah business model yang hanya berlaku bagi kegiatan bisnis tersebut.

Situasi semacam ini sesungguhnya tidak hanya terjadi pada pelaku bisnis yang memulai usaha barunya tetapi bisa saja terjadi pada perusahaan yang sudah lama eksis. Sebagai contoh, ketika departemen R\&D Xerox menghasilkan mesin foto copy, Richard D. Irwin yang ditunjuk sebagai konsultan untuk mengevaluasi pasar mengatakan bahwa mesin foto copy tersebut tidak layak jual meski secara teknologi sangat baik (Chesbrough and Rosenbloom, 2002). Akibatnya perusahaan harus memutar otak untuk menemukan cara memasarkan

\footnotetext{
${ }^{1}$ Draft awal dari paper ini telah dipresentasikan pada Conference International South East Asian Association for Institutional Research, Bangkok 5-7 September 2007
} 
hasil temuannya yang telah menghabiskan investasi cukup besar. Akhirnya ditemukan sebuah business model yang cocok untuk temuannya tersebut. Xerox memutuskan untuk "menyewakan bukan menjual mesin fotocopy - leasing not selling the product" sebagai business modelnya (Chesbrough and Rosenbloom, 2002). Kondisi yang tidak jauh berbeda juga dialami Dell Corporation. Tidak seperti perusahaan pabrikan Personal Computer lain, Dell memilih business model yang khas yaitu "make to order and make money before the product is delivered menjual produk sesuai dengan pesanan dan menerima pembayaran sebelum produk diserahkan" (Kraemer, Derick and Yamashiro, 2000). Dengan business model tersebut Dell menuai sukses yang ditunjukkan dengan angka penjualan dan laba yang tinggi dan terus meningkat (lihat misalnya: Magretta, 1998).

Uraian diatas menggambarkan bahwa setiap perusahaan bahkan setiap organisasi selalu berupaya membangun business model sebagai dasar untuk menjalankan aktivitas bisnisnya dan dalam rangka menciptakan nilai tambah. Pada umumnya, meski bukan keharusan (Magretta, 2002), business model (untuk selanjutnya disingkat BM) bagi sebuah perusahaan/organisasi merupakan pilihan yang khas dan unik yang belum tentu cocok bagi perusahaan/organisasi lain (Owens, 2006). Diharapkan dengan kekhasan BM tersebut perusahaan bisa menciptakan nilai tambah sesuai dengan kebutuhan para pelanggan. Bagi perusahaan itu sendiri BM yang tepat diharapkan bisa membantu menuai hasil sesuai dengan tujuan awal didirikannya perusahaan. Menurut Chesbrough and Rosenbloom (2002), fungsi dari business model adalah sebagai berikut:

1. Mengartikulasikan value proposition sebuah organisasi yaitu bagaimana Menciptakan nilai tambah bagi para pengguna (customers).
2. Mengidentifikasi target pasar.

3. Menentukan bagaimana menciptakan value chain (rantai nilai) dalam proses operasionalisasi organisasi.

4. Memperkirakan besaran biaya dan pendapatan yang diperoleh sebagai akibat ditetapkannya value proposition dan value chain.

5. Menjelaskan posisi organsasi dalam kaitannya dengan jejaring penciptaan nilai tambah.

6. Memformulasikan strategi bisnis.

Meski demikian, memilih BM harus dilakukan secara hati-hati karena beberapa alasan berikut. Pertama, cara memilih BM biasanya tidak didasarkan pada alasan-alasan rasional. Sebaliknya cara memilihnya lebih bersifat subyektif, intuitif dan tidak ada ukuran-ukuran standard yang bisa dijadikan dasar untuk membenarkan pilihan tersebut. Apakah pilihan tersebut tepat atau tidak, tentunya tidak bisa segera diketahui. Ketepatan pilihan tersebut baru bisa diketahui beberapa waktu kemudian setelah terbukti bahwa BM tersebut membawa hasil. Sebaliknya pilihan tersebut dianggap gagal jika penciptaan nilai tambah yang menjadi tujuannya tidak tercapai. Kedua, keberhasilan sebuah perusahaan tidak ditentukan semata-mata oleh BM saja tetapi juga bagaimana pihak manajemen menterjemahkan BM kedalam kegiatan opersional perusahaan. Magretta (2002) misalnya mencontohkan bahwa BMnya Wal Mart sesungguhnya tidak berbeda dengan Circle K namun Wal Mart jauh lebih berhasil karena menerapkan strategi berbeda. Persoalan ketiga adalah sampai saat ini belum ada teori dan panduan baku yang bisa membantu para praktisi menyusun BM dengan tepat. Penyebabnya karena dalam ranah ilmu manajemen, BM baik secara teori maupun konsep masih berada pada tahap embryonic (Schweizer, 2005).

Terlepas dari kendala memilih BM yang tepat, dan masih ada yang pesimis akan 
kegunaan BM (Porter, 2001), Magretta (2002) menegaskan: "a good business model remains essential to every successful organization, whether it's a new venture or an established player - BM tetap saja merupakan hal yang penting bagi setiap organisasi yang menghendaki keberhasilan, apakah organisasi tersebut adalah organisasi baru atau organisasi yang sudah lama eksis". Penjelasan ini menegaskan adanya kebutuhan, kalau tidak dikatakan keharusan, untuk memilih dan menyusun BM yang tepat agar kegiatan organisasi bisa berjalan lebih lancar sesuai dengan harapan konstituen.

Dengan memperhatikan adanya kebutuhan untuk memilih dan menyusun BM, dan di sisi lain para praktisi masih menemui kesulitan dalam menyusun BM karena belum adanya panduan baku dan belum mapannya teori BM, paper ini berusaha melakukan telaah literatur yang berkaitan dengan konsep BM. Disamping itu paper ini juga akan memberikan gambaran empiris proses penyusunan BM pada sebuah organisasi nirlaba. Ada dua hal yang harus dipahami dari paper ini. Pertama, seperti dikatakan Lambert (2002) istilah BM sesungguhnya tidak hanya berlaku bagi organisasi berorientasi laba tetapi juga organisasi nirlaba. Oleh karenanya tidak ada alasan untuk tidak membahas BM pada organisasi nirlaba. Kedua, seperti pada umumnya kajian terhadap penyusunan BM (lihat misalnya: Barraba, 2002; Looney et al. 2004)), paper ini hanya menggunakan kasus tunggal maka hasil kajian dari paper ini mungkin tidak bisa digeneralisasi untuk kasus-kasus yang lain meski diharapkan paper ini bisa memberi tambahan informasi dan inspirasi bagi praktisi lain yang sedang berusaha menyusun BM.

Paper ini dibagi menjadi tiga bagian. Bagian pertama merupakan telaah literature untuk memperoleh gambaran tentang konsep BM. Termasuk pada bahasan pada bagian ini adalah definisi BM, komponen BM dan penyusunan dan perubahan BM. Bagian kedua pengalaman empiris proses penyusunan BM. Pada bagian ini sekaligus didiskusikan pula metode penyusunan BM. Bagian ketiga simpulan dan insight bagi para manajer yang berkehendak menyusun BM.

\section{TELAAH LITERATUR}

Bagian ini menelaah konsep Business model meski belum sampai pada telaah teori karena sampai saat ini belum ada teori yang mapan tentang BM (Lambert, 2003a,b; Schweizer, 2005). Telaah konsep ini diharapkan bisa menjadi landasan berpijak untuk menjelaskan proses penyusunan BM. Hal-hal penting yang akan dibahas pada bagian ini adalah definisi BM, komponen BM, taksnomi BM, perbedaan antara BM dan strategi, dan perubahan BM.

\section{Definisi Business model}

Business model merupakan istilah yang relatif baru. Istilah ini muncul pertama kali pada tulisan Robert Keidel (1984) Baseball, Football, and Basketball: Models for Business. Jauh sebelum Keidel, yakni sekitar tahun 1970an, istilah business model sesungguhnya sudah dikenal (Stahler, 2001 sebagaimana dikutip oleh Bouwman, 2003). Hanya saja ketika itu konsep BM lebih diorientasikan dan digunakan untuk memetakan pola proses bisnis dan system informasi dan komunikasi dalam rangka membangun system informasi teknologi. Keidel sendiri ketika menyampaikan gagasannya tentang BM belum memberikan definisi yang tegas tentang apa itu BM, Ia hanya mengatakan bahwa jenis-jenis olahraga (dalam hal ini Baseball, Football, and Basketball) bisa menjadi model untuk menjalankan aktivitas organisasi. Keidel lebih lanjut mengatakan:

"tiga jenis olehraga yang sangat popular di Amerika - baseball, 
football dan basketball - menunjukkan dinamika yang berbeda dan menggambarkan tiga pola umum organisasi bisnis (dan sektor lainnya). Masing-masing jenis olahraga tersebut merepresentasikan sebuah model yakni satu set hubungan yang koheren yang menggambarkan esensi dari satu bentuk organisasi. Dengan mempelajari model-model ini, para manajer diyakini bisa memperoleh pemahaman untuk dirinya bagaimana menjalankan kegiatan organisasi".

Penjelasan di atas menegaskan bahwa kegiatan olah raga seperti Baseball, Football dan Basketball bukan sekedar olahraga tetapi bisa menjadi model untuk menjalankan aktivitas bisnis dan kegiatan organisasi lainnya. Alasannya karena masingmasing jenis olahraga mempunyai karakteristik tersendiri yang khas. Sebagai contoh, organisasi yang tersebar di beberapa tempat dimana masing-masing unit bersifat semi otonom (seperti pada umumnya holding company dan organisasi yang beroperasi berdasarkan franchise), memiliki kesamaan dengan karakteristik sebuah team baseball. Organisasi semacam ini cenderung menerapkan pola manajemen yang longgar kepada masing-masing unit aktivitas. Layaknya dosen perguruan tinggi, masing-masing unit memperoleh keleluasaan untuk mencapai tujuannya dalam rangka mencapai tujuan menyeluruh organisasi. Organisasi seperti ini biasanya memiliki satu prinsip - the whole is roughly sum of its parts (units) satu kesatuan merupakan penjumlahan dari masing-masing bagian (unit) yang mandiri. Dengan kata lain, organisasi dengan pola baseball team tentunya lebih menekankan pentingnya peran dan kompetensi individu ketimbang kerjasama tim sebagai kekuatan organisasi. Penjelasan yang kurang lebih sama berlaku bagi organisasi berpola foot- ball team dan basketball team masingmasing dengan karakteristiknya.

Tulisan Keidel sayangnya tidak banyak mendapat respon dari para praktisi bisnis atau para akademisi lain akan pentingnya memahami BM. Respon baru muncul 14 tahun kemudian menjelang akhir tahun 1990an, itupun boleh jadi bukan karena tulisan Keidel tetapi lebih disebabkan karena kemajuan teknologi informasi (khususnya internet) yang mendorong maraknya e-business. Seperti dikatakan Amit and Zott (2001) menjelang akhir tahun 1990an perkembangan bisnis melalui internet mengalami kemajuan luar biasa. Di Eropa misalnya pendapatan dari bisnis melalui internet naik dari US\$ 8.5 milyar pada akhir tahun 2000 menjadi US\$ 19.2 milyar pada tahun 2001. Kemajuan ini tentunya menjadi daya tarik tersendiri bagi para investor untuk menanamkan dananya ke e-business (biasa juga disebut sebagai $e$ commerce atau I-business). Tetapi sayangnya tidak sedikit pula $e$-business yang tibatiba jatuh bangkrut. Salah satu alasan jatuhbangkrutnya e-business adalah mereka masih menerapkan BM konvensional meski secara operasional "brick-and-mortarbusiness" - bisnis konvensional berbeda dengan "click-and-mortar-business" $-e$ business berbasis dotcom (Vickers, 2002; Mansfield, Fourie and Gevers, 2005). Belajar dari pengalaman tentang banyaknya bisnis dotcom yang gagal tetapi di sisi lain bisnis tersebut dianggap prospektif, para investor sebelum menginvestasikan uangnya ke $e$-business biasanya terlebih dahulu mempertanyakan bagaimana e-business tersebut bisa menciptakan nilai tambah dan menghasilkan uang. Atau sederhananya bagaimana BM-nya? Dari pertanyaan inilah istilah BM menjadi popular, khususnya di kalangan pelaku e-business, consultant, dan para akademisi - khususnya akademisi yang berlatar belakang disiplin ekonomi, mana- 
jemen (strategi dan pemasaran) dan utamanya Sistem Informasi.

Meski istilah MB sudah mulai popular, sebagai bidang kajian yang relatif baru, tidak pungkiri jika pemahaman tentang konsep BM masih simpang siur (Alt and Zimmermann, 2001; Petrovic, Kittl and Teksten, 2001). Meminjam istilah yang biasa digunakan oleh Richers and Schneider (1990) bisa dikatakan bahwa BM secara konseptual masih berada pada tahap embryonic (Lambert 2006a,b). Oleh sebab itu tidak mengherankan pula jika definisi business model sampai saat ini belum dirumuskan secara baku (Pateli and Giaglis, 2002). Sebagian mendefinisikan BM secara garis besar. Termasuk dalam kelompok ini misalnya Timmers (1998), Magretta (2002), Linder and Cantrell (2000), dan Rappa (2007). Sebagiannya lagi mendefinisikan BM secara detail mencakup hampir semua fungsi bisnis (Mahadevan, 2000; Chesbrough and Rosenbloom, 2002; Osterwalder and Pigneur, 2002). Bahkan ada sebagiannya lagi hanya mengulas salah satu aspek dari BM (lihat misalnya: Linder and Cantrell, 2000). Untuk memberi gambaran tentang keberagaman definisi BM, Tabel 1 menyajikan definisi BM dari berbagai literatur baik yang bersifat umum maupun yang detail.

Tabel 1: Definisi Business model

\begin{tabular}{|l|l|}
\hline \multicolumn{1}{|c|}{ Authors } & \multicolumn{1}{c|}{ Definition } \\
\hline Magretta (2002) & A story that explain how an enterprise work \\
\hline Petrovic et al. (2001) & $\begin{array}{l}\text { A description of the logic of a "business system" for creating value that lies } \\
\text { behind the actual process }\end{array}$ \\
\hline $\begin{array}{l}\text { Osterwalder and Pigneur } \\
\text { (2002) }\end{array}$ & $\begin{array}{l}\text { A description of the value a company offers to one or several segment of } \\
\text { customers and the architecture of the firm and its network of partners for } \\
\text { creating, marketing and delivering this value and relationship capital, in order } \\
\text { to generate profitable and sustainable revenue streams }\end{array}$ \\
\hline Weill and Vitale (2001) & $\begin{array}{l}\text { A description of the roles and relationships among a firm's consumers, } \\
\text { customers, allies and suppliers that identifies the major flows of product, } \\
\text { information, and money, and the major benefits to participants }\end{array}$ \\
\hline Timmers (1998) & $\begin{array}{l}\text { An architecture for the product, service and information flow, including a } \\
\text { description of the various business actors and their roles; and a description of } \\
\text { the potential benefiits for various actors; and description of the sources of } \\
\text { revenues }\end{array}$ \\
\hline Rappa (2007) & $\begin{array}{l}\text { The method of doing business by which a company can sustain itself }- \text { that is } \\
\text { generate revenue. The business model spells-out how a company makes } \\
\text { money by specifying where it is positioned in the value chain }\end{array}$ \\
\hline $\begin{array}{l}\text { Chesbrough and Rosenbloom } \\
\text { (2002) }\end{array}$ & $\begin{array}{l}\text { A description of how your company intends to create value in the market } \\
\text { place. It includes that unique combination of products, services, image, and } \\
\text { distribution that your company carries forward. It also includes the underlying } \\
\text { organization of people, and the operational infrastructure that they use to } \\
\text { accomplish their work }\end{array}$ \\
\hline Mahadevan (2002) & $\begin{array}{l}\text { A unique blend of three streams, which are critical to the business. These } \\
\text { include the value stream for the business partners and the buyer, the } \\
\text { revenue stream, and the logistical stream. }\end{array}$ \\
\hline The organization's core logic for creating value \\
\hline
\end{tabular}


Dari beragam definisi di atas bisa ditarik simpulan sementara bahwa business model merupakan upaya sebuah organisasi/perusahaan untuk menciptakan nilai tambah bagi konstituen yang dilayaninya dan menghasilkan income bagi organisasi bersangkutan (Alt and Zimmermann, 2001). Upaya tersebut merupakan upaya yang khas yang hanya dimiliki oleh sebuah organisasi dan tidak dimiliki serta tidak mudah diimitasi organisasi sejenis (Mahadevan, 2002). Karena kekhasannya itu BM diperlakukan sebagai kerangka pikir (construct) dan menjadi pedoman bagi sebuah organisasi dalam menjalankan bisnis - memberikan layanan, menciptakan nilai tambah dan menghasilkan pendapatan. Namun harus disadari pula bahwa BM hanyalah sebuah model yang merepresentasikan realitas (Petrovic, Kittl and Teksten, 2001). Artinya, BM terkadang lebih berkonsentrasi pada satu aspek organisasi tertentu dan mengabaikan aspek lain.

\section{Komponen Business model}

BM adalah sebuah construct. Artinya agar BM bisa operasional perlu dipahami elemen-elemen yang membentuk BM tersebut. Persoalannya, seperti halnya dengan persoalan definisi BM, sejauh ini belum ada kesepakatan diantara penggagas konsep BM tentang nama, jumlah dan jenis elemen pembentuk BM. Dari telaah literatur diketahui bahwa elemen inti BM kadangkadang disebut: komponen, fungsi, atribut atau pilar BM (Pateli and Giaglis, 2004). Sebagai contoh, Chesbrough and Rosenbloom (2002) menggunakan istilah fungsi dan Osterwalder and Pigneur (2002) menamakannya pilar, masing-masing untuk komponen BM. Demikian juga jumlah dan jenis elemen pembentuk BM, seperti tampak pada
Tabel 2, bervariasi (Pateli and Giaglis, 2002). Semua perbedaan ini tidak lepas dari perbedaan latar belakang akademik para penggagas konsep BM itu sendiri. Dampaknya berujung pada perbedaan pendekatan yang digunakan untuk mengungkap komponen BM.

Seperti dikatakan Pateli and Giaglis (2004), ada tiga pendekatan yang secara umum biasa digunakan untuk mengelaborasi komponen BM. Ketiga pendekatan tersebut adalah:

1. Top down analysis dan hierarchical decomposition. Dengan pendekatan ini dilakukan dekomposisi aktivitas bisnis yang lebih general kedalam komponen yang lebih konkret dan detail sebagai pijakan untuk mengalisis BM. Cara ini misalnya dilakukan oleh Weill and Vitale (2000). Sementara itu Linder and Cantrell (2000) dan Petrovic et al. (2001) mendekomposisi BM kedalam sub-model dan menghubungkan satu sub-model dengan sub-model lainnya secara hirarkhis.

2. Matrix analysis. Cara kedua dilakukan Alt and Zimmermann (2001) dengan membuat matriks berupa sumbu vertical dan horizontal. Dalam hal ini sumbu vertical merepresentasi komponen inti yang berfungsi untuk mengkomunikasikan komponen inti BM. Sedangkan sumbu horizontal digunakan untuk men-set up kerangka kontektual berkaitan dengan implementasi BM

3. Value analysis. Dengan cara ketiga BM diterjemahkan kedalam komponen inti yang memberi kontribusi terbesar dalam penciptaan nilai tambah sementara komponen yang lain diperlakukan sebagai komplementer. 
Tabel 2: Komponen Business model

\begin{tabular}{|c|c|c|}
\hline & Penulis & Komponen \\
\hline 1. & Afuah and Tucci (2000) & $\begin{array}{ll}\text { 1. } & \text { Customer value } \\
\text { 2. } & \text { Scope } \\
\text { 3. } & \text { Pricing } \\
\text { 4. } & \text { Revenue source } \\
\text { 5. } & \text { Connected activities } \\
\text { 6. } & \text { Implementation } \\
\text { 7. } & \text { Capabilities } \\
\text { 8. } & \text { Sustainabilities }\end{array}$ \\
\hline 2. & Alt and Zimmermann (2001) & $\begin{array}{ll}\text { 1. } & \text { Mission } \\
\text { 2. } & \text { Structure } \\
\text { 3. } & \text { Process } \\
\text { 4. } & \text { Revenues } \\
\text { 5. } & \text { Technology } \\
\text { 6. } & \text { Legal issues }\end{array}$ \\
\hline 3. & Chesbrough and Rosenbloom (2000) & $\begin{array}{ll}\text { 1. } & \text { Value proposition } \\
\text { 2. } & \text { Market segment } \\
\text { 3. } & \text { Structure of the value chain } \\
\text { 4. } & \text { Cost structure and profit petential } \\
\text { 5. } & \text { Position of the firm } \\
\text { 6. } & \text { Competitve strategy }\end{array}$ \\
\hline 4. & Osterwalder and Pigneur (2002) & $\begin{array}{ll}\text { 1. } & \text { Product innovation } \\
\text { 2. } & \text { Customer relationship } \\
\text { 3. } & \text { Infrastructur management } \\
\text { 4. } & \text { Financials } \\
\end{array}$ \\
\hline 5. & Petrovic, Kittl and Teksten (2001) & $\begin{array}{ll}\text { 1. } & \text { Value model } \\
\text { 2. } & \text { Resource model } \\
\text { 3. } & \text { Production model } \\
\text { 4. } & \text { Customer relations model } \\
\text { 5. } & \text { Revenue model } \\
\text { 6. } & \text { Capital model } \\
\text { 7. } & \text { Market model } \\
\end{array}$ \\
\hline 6. & Linder and Cantrell (2000) & $\begin{array}{ll}\text { 1. } & \text { Pricing model } \\
\text { 2. } & \text { Revenue model } \\
\text { 3. } & \text { Channel model } \\
\text { 4. } & \text { Commerce-process model } \\
\text { 5. } & \text { Internet-enabled commerce model } \\
6 . & \text { Organizational form } \\
\text { 7. } & \text { Value proposition }\end{array}$ \\
\hline 7. & Kraemer et al. (2000) & $\begin{array}{ll}\text { 1. } & \text { Direct sales } \\
\text { 2. } & \text { Direct customer relationship } \\
\text { 3. } & \text { Customer segmentation } \\
\text { 4. } & \text { Production }\end{array}$ \\
\hline 8. & Mahadevan (2000) & $\begin{array}{ll}1 . & \text { Value stream } \\
2 . & \text { Revenue stream } \\
\text { 3. } & \text { Logistical stream } \\
\end{array}$ \\
\hline 9. & Weill and Vitale (2000) & $\begin{array}{ll}\text { 1. } & \text { Atomic business model } \\
\text { 2. } & \text { E-business model } \\
\text { 3. } & \text { E-business initiative } \\
\text { 4. } & \text { E-business implementation }\end{array}$ \\
\hline
\end{tabular}


Terlepas dari perbedaan cara dalam mengidentifikasikan komponen $\mathrm{BM}$, yang pasti semuanya itu diharapkan bisa membantu memahami the logic of business model - baik dari sisi praktis maupun teoritik. Dari beberapa literatur juga diketahui bahwa komponen yang paling sering muncul adalah misi, target market, proposisi nilai, aktivitas kunci, model biaya dan pendapatan, dan rantai nilai. Artinya, untuk membangun BM perlu terlebih dahulu dipahami filosofi bisnisnya itu sendiri yang tercantum dalam misi perusahaan, kemudian diterjemahkan kedalam BM dan diterjemahkan lebih lanjut kedalam elemen-elemen lainnya. Jika komponen-komponen diatas disederhanakan maka secara umum bisa dikatakan bahwa business model pada dasarnya mencakup dua area utama yaitu:

1. Area internal. Pada area ini business model lebih difungsikan sebagai sarana untuk mempertahankan efisiensi dan efektifitas proses bisnis - menciptakan produk, jasa, citra dan mendistribusikannya dengan cara-cara yang unik dan spesifik. Termasuk didalamnya menetapkan kebutuhan sumberdaya organisasi, sumber dan penggunaan dana, dan membuat perencanaan dan pengendalian aktivitas proses bisnis internal,

2. Area external. Pada area ini business model lebih difungsikan sebagai sarana untuk beradaptasi dengan lingkungan eksternal - khususnya dalam mengantisipasi kebutuhan dan harapan para konstituen. Oleh karenanya siapa konstituen yang akan dipuaskan kebutuhannya perlu diidentifikasikan secara jelas agar organisasi tersebut bisa menghasilkan sesuatu sesuai dengan harapan konstituen.

\section{Taksonomi Business model}

Di muka disebutkan bahwa sejauh ini belum ada standard baku untuk menyusun $\mathrm{BM}$ sehingga setiap pelaku bisnis dan pengelola organisasi lainnya bisa membangun BM sesuai dengan kepentingan dan orientasi masing-masing. Meski demikian upaya-upaya sistematik untuk menyusun model baku BM telah dimulai. Weill et al. (2005) misalnya menawarkan sebuah model yang disebut "MIT Business model Architypes (BMAs)" dan Business model Ontology - BMO (Osterwalder, 2004). Secara umum ada dua faktor utama yang dipertimbangkan untuk menyusun BM, yaitu: (1) komponen BM - apa yang dilakukan oleh sebuah organisasi bisnis sehingga bisnis tersebut bisa menghasilkan uang, dan (2) klasifikasi BM itu sendiri. Penjelasan tentang komponen $\mathrm{BM}$ telah dibahas dan berikutnya adalah penjelasan tentang klasifikasi BM. Keen and Qureshi (2005) dan Lambert $(2006 a, b)$ menegaskan bahwa untuk kepentingan analisis konsep dan pengembangan teori perlu terlebih dahulu disusun klasifikasi BM. Menurut Lambert (2006a) klasifikasi yang paling umum adalah membedakan antara tipologi dan taksonomi. Meski kedua istilah ini sering digunakan secara bergantian, keduanya sesungguhnya memiliki karakteristik yang berbeda seperti tampak pada Tabel 3 .

Tabel 3: Perbedaan antara Tipologi dan Taksonomi

\begin{tabular}{|c|c|}
\hline Tipologi & Taksonomi \\
\hline Klasifikasi secara khusus/arbriter/artificial & Klasifikasi umum/natural \\
\hline Kategorisasi berdasar konsep & Kategorisasi secara empiris \\
\hline Bersifat deduktif & Induktif \\
\hline Hanya mempertimbangkan beberapa karakteristik & Mempertimbangkan berbagai macam karakteristik \\
\hline Biasanya bersifat kualitatif & Klasifikasi kuantitatif \\
\hline Generalisasi secara terbatas & Sebagai dasar untuk generalisasi \\
\hline Sumber: Lambert (2006a)
\end{tabular}


Tabel 4: Klasifikasi Business Model

\begin{tabular}{|c|c|c|c|c|c|}
\hline Penulis & Timmer (1998) & Bambury (1998) & $\begin{array}{l}\text { Linder and Cantrell } \\
(2000)\end{array}$ & Betz (2002) & Rappa (2007) \\
\hline $\begin{array}{l}\text { Diakui oleh penulis } \\
\text { sebagai }\end{array}$ & Current Business Model & Taxonomy & $\begin{array}{l}\text { Overview of Operating } \\
\text { Business Models }\end{array}$ & $\begin{array}{l}\text { Generic Business } \\
\text { Model }\end{array}$ & $\begin{array}{l}\text { Taxonomy of BM on } \\
\text { the Web }\end{array}$ \\
\hline Kriteria pembeda & $\begin{array}{l}\text { Tingkat Inovasi } \\
\text { Tingkat integrasi }\end{array}$ & No consistent criteria & $\begin{array}{l}\text { Core profit making } \\
\text { activity } \\
\text { Relative posistion on } \\
\text { the price/value } \\
\text { continuum }\end{array}$ & $\begin{array}{l}\text { Resource, sales, } \\
\text { profit, capital }\end{array}$ & No consistent criteria \\
\hline $\begin{array}{l}\text { Jumlah kategori } \\
\text { dan sub-kategori }\end{array}$ & 11 kategori & $\begin{array}{l}2 \text { categories } \\
15 \text { subcategories }\end{array}$ & $\begin{array}{l}8 \text { categories } \\
34 \text { subcategories }\end{array}$ & 6 categories & $\begin{array}{l}9 \text { categories } \\
41 \text { subcategories }\end{array}$ \\
\hline Kategori BM & $\begin{array}{l}\text { E-shop } \\
\text { E-procurement } \\
\text { E-malls } \\
\text { E-auctions } \\
\text { Virtual communities } \\
\text { Collaboration platform } \\
\text { Third-party marketplaces } \\
\text { Value-chain integrators } \\
\text { Value-chain service } \\
\text { providers } \\
\text { Information brokerage } \\
\text { Trust services }\end{array}$ & $\begin{array}{l}\text { Translated real-world business } \\
\text { model } \\
\text { Mail-order model } \\
\text { Advertising-based model } \\
\text { Subsciption model } \\
\text { Free trial model } \\
\text { Direct marketing model } \\
\text { Real estate model } \\
\text { Incentive scheme model } \\
\text { B2B } \\
\text { Combination of the above model } \\
\text { Native internet business model } \\
\text { Library model } \\
\text { Freeware model } \\
\text { Information barter model } \\
\text { Digital product \& digital delivery } \\
\text { model } \\
\text { Access provision model } \\
\text { Website hosting \& other model }\end{array}$ & $\begin{array}{l}\text { Price model } \\
\text { Convenience model } \\
\text { Commodity plus model } \\
\text { Experience model } \\
\text { Channel model } \\
\text { Intermediary } \\
\text { Trust model } \\
\text { Innovation model }\end{array}$ & $\begin{array}{l}\text { Strategic finance } \\
\text { Strategic enterprise } \\
\text { Strategic response } \\
\text { Strategic learning } \\
\text { Strategic innovation } \\
\text { Strategic firm }\end{array}$ & $\begin{array}{l}\text { Brokerage } \\
\text { Advertising model } \\
\text { Infomediary model } \\
\text { Merchant model } \\
\text { Manufacturer model } \\
\text { Affiliate model } \\
\text { Community model } \\
\text { Subscription model } \\
\text { Utility model }\end{array}$ \\
\hline
\end{tabular}


Dengan menggunakan kriteria seperti tersebut pada Tabel 3, Lambert lebih lanjut mengatakan bahwa sejauh ini belum ada literatur BM yang secara riil mengklasifikasikan BM kedalam taksonomi BM. Klasifikasi BM lebih banyak menggunakan tipologi. Memang ada sebagian yang mengklaim telah mengklasifikasikan BM kedalam taksonomi meski klasifikasi tersebut sesungguhnya hanyalah tipologi. Beberapa contoh klasifikasi $\mathrm{BM}$ kedalam tipologi dapat dilihat pada Tabel 4. Klasifikasi BM kedalam tipologi bukan tidak bermanfaat karena klasifikasi tersebut merupakan langkah awal untuk menyusun taksonomi BM yang secara berturut-turut menjadi landasan untuk menyusun teori BM. Oleh karenanya tipologi BM yang masih beragam seperti tampak pada Tabel 4 perlu diintegrasikan dan dikonsolodasikan kedalam tipologi lebih komprehensif.

\section{Business Model vs. Strategi}

Setelah memperoleh gambaran umum tentang esensi BM termasuk didalamnya definisi, komponen dan klasifikasi $\mathrm{BM}$, pertanyaan penting yang masih tersisa adalah dimana kedudukan BM dalam arsitektur organisasi secara keseluruhan. Pertanyaan ini muncul karena jauh sebelum konsep BM banyak dibicarakan orang, dalam bidang studi manajemen telah berkembang satu konsep dan teori yang telah mapan yaitu strategi bisnis. Dilihat dari pengertian maupun fungsinya, kedua konsep ini memiliki kemiripan sehingga dalam praktik istilah BM dan strategi sering digunakan secara bergantian (Seddon, et al., 2004). Hanya saja mereka yang berlatar belakang teknologi informasi yang menjadi inisiator munculnya konsep BM lebih banyak menggunakan istilah BM ketimbang strategi (Seddon et al., 2004). Sebaliknya, mereka yang berlatar belakang manajemen cenderung mempertanyakan, bahkan menolak (Porter, 2001), apakah masih bermanfaat membicarakan BM. Meski demikian, mengingat tidak sedikit yang secara tegas membedakan BM dan strategi (Chesbrough and Rosenbloom, 2002; Magretta, 2002; Osterwalder and Pigneur, 2002 - untuk menyebut beberapa) ada baiknya kedua konsep tersebut dikontraskan untuk menghindari kerancuan lebih lanjut dan agar bahasan tentang BM mempunyai makna. Untuk itu, berdasarkan berbagai literatur yang ada dan dengan bantuan diagram Venn seperti tampak pada gambar 1, Seddon et al. (2004) mencoba mengklarifikasi keterkaitan antara BM dan strategi.

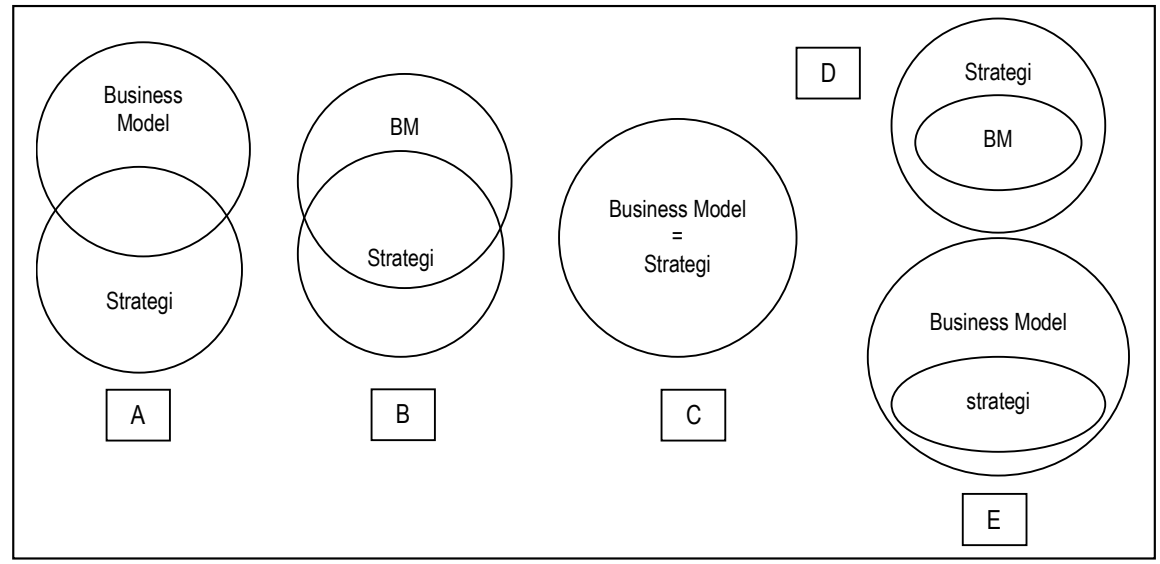

Gambar 1: Overlap antara BM dan Strategi 


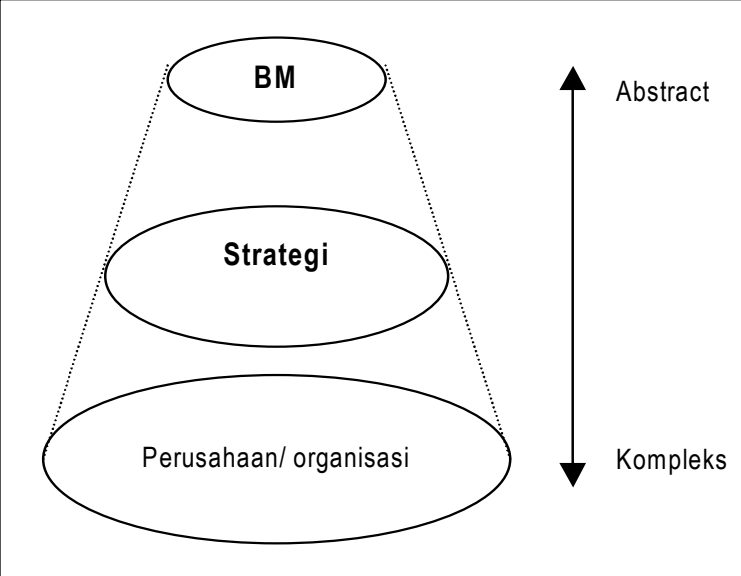

Gambar 2: Hubungan antara BM, Strategi dan Realitas Perusahaan/Organisasi

Lima kemungkinan hubungan antara BM dan strategi seperti tampak pada gambar 1, menunjukkan situasi yang dilematis untuk membedakan kedua konsep tersebut. Overlapping hampir tidak bisa dihindarkan. Hanya saja, secara konseptual perdebatan paling sering muncul adalah kemungkinan 1.C, yakni BM sama dengan strategi, 1.D - BM merupakan abstraksi dari strategi, dan 1.E - strategi merupakan abstraksi dari BM. Jika kemungkinan 1.C yang diambil maka sesungguhnya tidak ada manfaatnya membicarakan BM karena BM dan strategi merupakan dua sisi dari satu mata uang. Artinya secara konseptual BM sudah dijelaskan secara detail pada teori strategi bisnis sehingga BM dalam bahasa Abrahamson (1996) hanyalah sebuah management fashion yang akan dilupakan orang dengan berlalunya waktu. Oleh karena itu agar pembahasan BM mempunyai makna dua kemungkinan yang berlawanan yakni 1.D dan 1.E akan menjadi pokok bahasan pada bagian ini.

Gambar 1.D menjelaskan bahwa BM merupakan abstraksi dari strategi. Gambaran lebih jauh tentang hubungan antara $\mathrm{BM}$ dengan strategi tersebut diperjelas dengan Gambar 2. Gambar 2 merupakan pengembangan dari gambar 1.D yang menegaskan bahwa BM merupakan abstraksi dari dunia nyata yang begitu kompleks yang dihadapi oleh sebuah perusahaan atau organisasi. Dalam hal ini strategi sama halnya dengan BM juga merupakan abstraksi. Bedanya, BM jauh lebih abstrak dan sangat mengesampingkan hal-hal detail dibandingkan strategi. Di samping itu, BM lebih merupakan construct yang mengedepankan nilai-nilai internal organisasi/perusahaan sedangkan strategi merupakan upaya untuk menterjemahkan construct tersebut dalam konteks persaingan dengan dunia di luar organisasi. Pandangan ini misalnya dianut oleh Magretta (2002) yang mengatakan bahwa BM is stories that explain how an enterprise works - sebuah kisah yang menjelaskan bagaimana sebuah organisasi berhasil menjalankan aktivitasnya. Dalam hal strategi, Magretta lebih lanjut mengatakan "dealing with reality is strategy's job. A competitive strategy explains how you will do better than your rival - menghadapi realitas adalah pekerjaan strategi ... Strategi kompetitif menjelaskan bagaimana anda melakukan yang lebih baik dibanding para pesaing". Penjelasan ini sekaligus menegaskan perbedaan antara BM dan strategi, 
dan mengukuhkan hirarkhi hubungan antara BM, strategi dan organisasi seperti tampak pada gambar 2. Pandangan ini selain dianut oleh Magretta, juga oleh Weill and Vitale (2001) dan Linder and Cantrell (2000) selain Seddon et al. (2004) sendiri yang cenderung berpandangan sama. Pandangan ini juga sesuai dengan klaim Pateli and Giaglis (2004) bahwa untuk menyusun BM terlebih dahulu dipahami misi perusahaan dilanjutkan dengan penyusunan BM dan komponenkomponen organisasi lainnya termasuk strategi.

Sementara itu gambar 1.E secara logic adalah kebalikan dari gambar 1.D. Artinya penjelasan detail gambar 1.E merupakan kebalikan dari penjelasan di atas di mana urut-urutannya adalah: Misi, strategi, BM dan diikuti oleh komponen-komponen organisasi lainnya. Pandangan ini misalnya dianut oleh Osterwalder dan kelompoknya (Osterwalder, 2004; Osterwalder and Pigneur, 2002; Gordijn, Osterwalder and Pigneur, 2005; dan Osterwalder, Pigneur and Tucci, 2005). Hirarkhi hubungan antara BM dan strategi menurut Osterwalder adalah sebagai berikut:

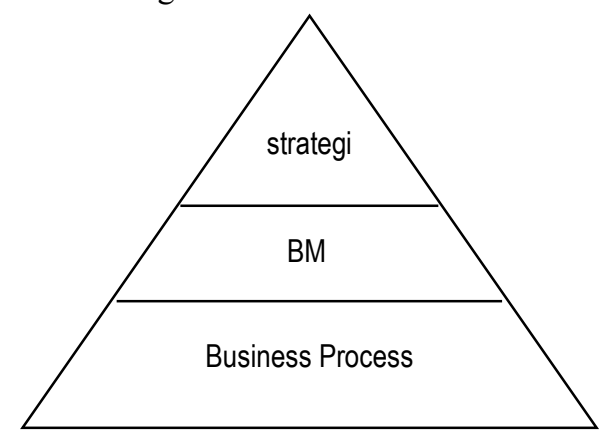

Gambar 3: Hirarkhi hubungan Strategi BM menurut Osterwalder (2004)

\section{Membangun dan Merubah BM}

Di muka telah dijelaskan bahwa setiap organisasi, bahkan sejak pertama kali organisasi tersebut didirikan, pasti memerlukan business model. Pada umumnya, me- mang BM dibangun bersamaan dengan didirikannya organisasi baru. Namun bukan berarti organisasi yang sudah lama eksis sama sekali tidak membutuhkan BM baru, terutama jika terjadi perubahan orientasi organisasi yang mendasar. Misalnya, terjadi perubahan dari brick-and-mortar-business ke click-and-mortar-business, atau seperti yang dialami Xerox ketika hendak memasarkan temuan barunya - mesin photo kopi.

Bagi organisasi yang telah lama eksis, meng-introdusir business model baru bukan pekerjaan mudah. Penyebab utamanya karena kita sudah terakulturasi dengan business model lama sehingga kita biasanya dihantui oleh perasaan takut jika business model baru justru lebih berisiko dibanding business model sebelumnya. Ketakutan seperti ini merupakan sebuah kewajaran karena merubah BM berarti merubah mental model (Auer and Follack, 2002). Artinya merubah mental model merupakan prasyarat bagi perubahan BM. Untuk itu ada tiga hal yang harus dilakukan secara berulang-ulang (iterative) yaitu (lihat: Auer and Follack, 2002):

1. Mapping mental models - tahap pertama adalah membuat peta tentang mental model berjalan. Tahapan ini dimaksudkan untuk memperoleh gambaran tentang asumsi-asumsi yang melandasi mental model tersebut beserta strukturnya.

2. Challenging mental models - memaparkan inkonsistensi terhadap asumsi yang digunakan

3. Improving mental models - secara terus menerus memperbaharui dan memperluas serta menguji mental model. Tujuannya tidak lain adalah untuk menemukan mental model baru.

Berdasarkan ketiga tahapan di atas, Auer and Follack (2002) mencontohkan bagaimana mereka membangun eBusiness model baru yaitu melalui tiga tahapan sebagaimana tampak pada Tabel 4. 
Tabel 4: Proses penyusunan BM

\begin{tabular}{|l|l|l|}
\hline Tahap & \multicolumn{1}{|c|}{ Langkah yang ditempuh } & \multicolumn{1}{c|}{ Tujuan } \\
\hline 1 & Memahami konsep BM & $\begin{array}{l}\text { Membantu organisasi dan peneliti saling berkomunikasi dan } \\
\text { memahami serta berbagi pengetahuan tentang BM }\end{array}$ \\
\hline 2 & $\begin{array}{l}\text { Mengidentifikasi dampak dari } \\
\text { internet }\end{array}$ & $\begin{array}{l}\text { Mengidentifikasi dampak internet, baik positif maupun negatif, } \\
\text { terhadap BM berjalan }\end{array}$ \\
\hline 3 & Melakukan perubahan BM & $\begin{array}{l}\text { Melakukan proses perubahan dan memahami serta } \\
\text { mendokumentasi semua dampak dari perubahan tersebut }\end{array}$ \\
\hline
\end{tabular}

\section{KASUS UNIVERSITAS ISLAM SWASTA}

Setelah memahami secara umum konsep business model, berikut ini akan disajikan studi kasus penyusunan BM pada sebuah organisasi perguruan tinggi - sebut saja namanya Universitas Islam Swasta (UIS). Penyusunan BM ini berangkat dari keinginan pihak universitas untuk merubah struktur organisasi UIS yang dianggap tidak lagi cocok dengan lingkungan perguruan tinggi yang telah mengalami banyak perubahan. Seperti halnya Perguruan Tinggi Swasta (PTS) lain, UIS sejak tahun 2001 menghadapi tekanan perubahan lingkungan yang berdampak pada semakin menurunnya jumlah mahasiswa mendaftar dan ujungujungnya berdampak pada ketidakstabilan keuangan universitas. Menanggapi perubahan ini, dan dalam upayanya untuk membenahi tata kelola organisasi, langkah awal yang ditempuh UIS adalah merubah struktur organisasi dan reward system yang (rencananya) diikuti oleh perubahan-peubahan internal lainnya. Penulis yang ketika itu ditunjuk sebagai konsultan untuk mengawal restrukturisasi UIS dalam perjalannya juga bertindak sebagai peneliti. Hal ini bisa di- artikan bahwa pekerjaan yang dilakukan penulis sekaligus diperlakukan sebagai kegiatan penelitian. Penelitian semacam ini biasa disebut sebagai "Penelitian tindakan atau action research" (Dick, 2002). Menurut Dick, action research adalah ".... a natural way of acting and reseaching at the same time - sebuah tindakan dan penelitian yang secara natural dilakukan pada waktu bersamaan". Yang dimaksud dengan tindakan disini adalah melakukan perubahan organisasi dalam rangka membantu client memecahkan persoalan yang dihadapinya. Sedangkan penelitian dimaksudkan untuk meningkatkan pengetahuan baik bagi peneliti itu sendiri maupun bagi client. Sederhananya dengan demikian, action research adalah bertindak dan meneliti. Hanya saja, dalam praktik, karena dua kegiatan tersebut dilakukan berbarengan terkadang sulit membedakan antara pekerjaan konsultasi dan action research seolaholah keduanya tidak bisa dipisahkan. Oleh karenanya action research sering dianggap tidak ilmiah. Terlepas dari kekurangan tersebut, Baskerville (1999) menegaskan bahwa sesungguhnya keduanya memiliki perbedaan seperti tampak pada Tabel 5 . 
SIIERGI Vol. 9 No. 2, JUNI 2007: 103 - 128

Tabel 5: Perbedaan antara Action Research dengan Konsultansi

\begin{tabular}{|l|l|l|}
\hline \multicolumn{1}{|c|}{ Unsur pembeda } & \multicolumn{1}{|c|}{ Action Research (AR) } & \multicolumn{1}{c|}{ Konsultansi } \\
\hline Motivasi & Termotivasi oleh prospek keilmuan & $\begin{array}{l}\text { Termotivasi oleh imbalan yang diberikan } \\
\text { client, juga pengetahuan karena bisa } \\
\text { memecahkan masalah organisasi }\end{array}$ \\
\hline Komitmen & $\begin{array}{l}\text { Berkomitmen terhadap komunitas } \\
\text { keilmuan untuk menghasilkan ilmu } \\
\text { pengetahuan, disamping kepada client }\end{array}$ & Komitmen hanya terhadap client \\
\hline Pendekatan & $\begin{array}{l}\text { Berkolaborasi dengan pihak yang diteliti } \\
\text { karena sifatnya yang idiographic }\end{array}$ & $\begin{array}{l}\text { Konsultan biasanya memposisikan } \\
\text { dirinya sebagai pihak independen } \\
\text { terhadap persoalan organisasi }\end{array}$ \\
\hline $\begin{array}{l}\text { Dasar untuk } \\
\text { memberi } \\
\text { rekomendasi }\end{array}$ & Dasarnya kerangka teoritik & $\begin{array}{l}\text { Konsultan biasanya diharapkan bisa } \\
\text { memberikan solusi untuk persoalan yang } \\
\text { dihadapi client }\end{array}$ \\
\hline $\begin{array}{l}\text { Esensi dalam } \\
\text { pemahaman } \\
\text { orgnisasional }\end{array}$ & $\begin{array}{l}\text { Pemahaman organisasional dilandasi } \\
\text { oleh keberhasilan melakukan perubahan } \\
\text { dalam praktik yang dilakukan secara } \\
\text { iterative }\end{array}$ & $\begin{array}{l}\text { Tim konsultan biasanya mengembangkan } \\
\text { pemahaman melalui analisis kritis } \\
\text { terhadap persoalan organisasi yang } \\
\text { dihadapi client }\end{array}$ \\
\hline
\end{tabular}

\section{Proses Penyusunan Business Model UIS}

Dimuka telah disebutkan bahwa usulan perubahan BM UIS pada awalnya bukan merupakan tujuan utama dari proyek pembenahan organisasi UIS. Tujuan utamanya, mengikuti pola pikir Cameron (1984) adalah menata ulang struktur organisasi dan reward system UIS dalam melakukan adaptasi organisasi. Hanya saja dalam perkembangannya, setelah melalui diskusi berulang dengan pihak UIS, disepakati bahwa sebagai bagian dari penataan ulang organisasi UIS masih dimungkinkan untuk melakukan perubahan BM UIS. Semua ini terjadi setelah Tim Konsultan menyusun rencana tindakan (action plan) dengan mengajukan desain perubahan berdasarkan arsitektur organisasi seperti tampak pada gambar 4 (catatan: untuk memahami lebih mendalam proses action research, lihat misalnya Auer and Follack, 2002).

Gambar 4 menunjukkan bahwa secara umum arsitektur sebuah organisasi paling tidak terdiri dari 8 komponen penting mulai dari poin A - Visi, proposisi nilai, tujuan, business dan revenue model, dan strategi bisnis sampai ke poin $\mathrm{H}$ - budaya organisasi. Disamping itu, gambar tersebut juga menunjukkan kelompok yang berkepentingan terhadap organisasi yakni stakeholders. Dari kedelapan komponen ini, poin A sering disebut sebagai komponen dasar organisasi yang dianggap sebagai ruh sebuah organisasi sehingga jarang mengalami perubahan. Meski demikian, hampir tidak bisa dihindari, diagnosis perubahan justru dimulai dari poin A yaitu menganalisis dan menginterpretasi ulang unsur fundamental organisasi UIS termasuk didalamnya telaah ulang business model UIS. Dari telaah ulang inilah disepakati untuk mengkaji lebih mendalam BM UIS. Dari kajian tersebut disimpulkan bahwa UIS perlu merubah BMnya sebagai langkah awal perubahan organisasi UIS. Artinya, dalam tulisan ini, berdasarkan action research study, perubahan BM menjadi topik utama sedangkan penataan ulang organisasi merupakan implikasi dari perubahan BM. 


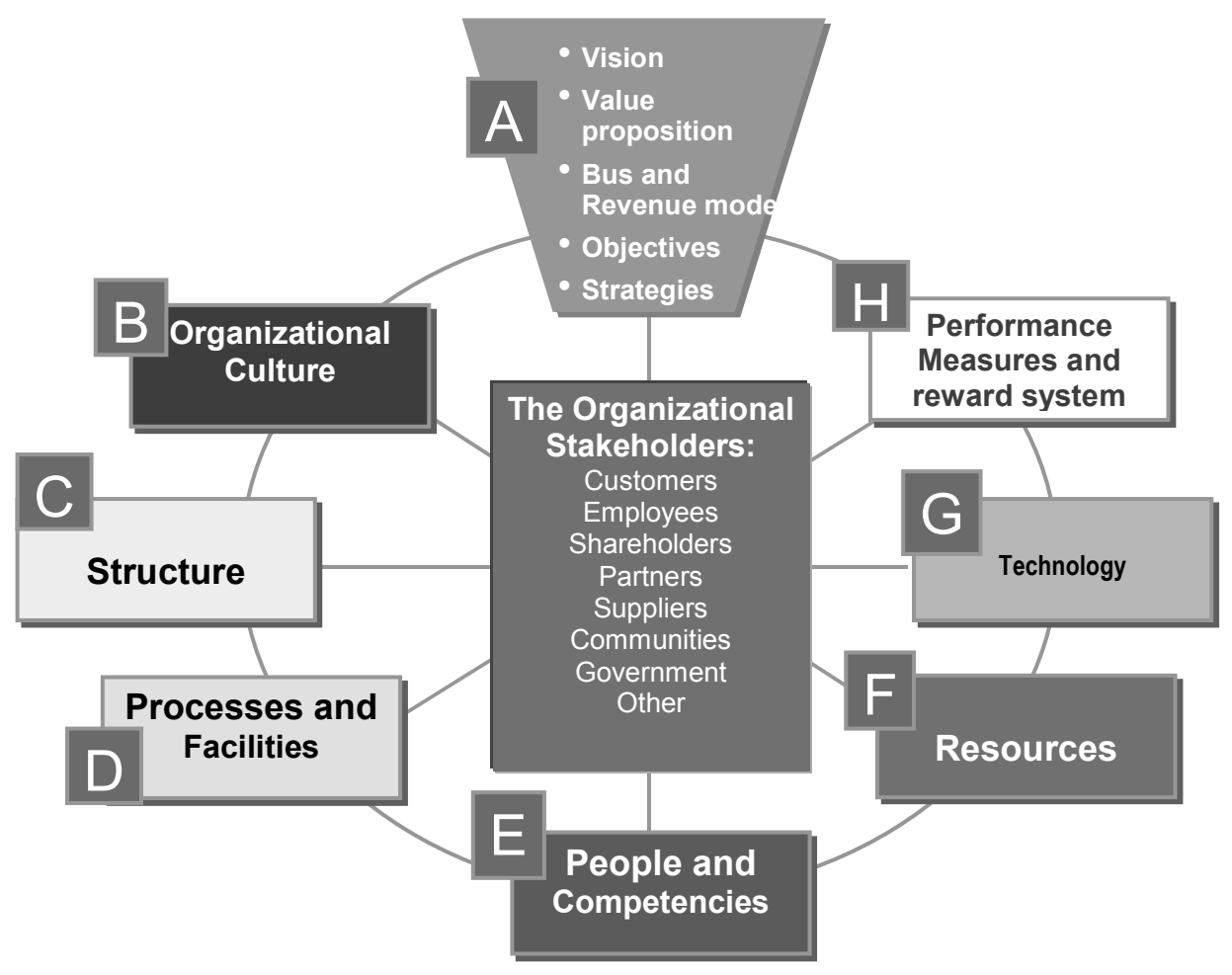

Gambar 4: Arsitektur Organisasi

\section{Desain Business model UIS}

Sebagai sebuah kerangka pikir (construct), BM merupakan sebuah pilihan yang khas bagi sebuah organisasi dan tidak mudah diimitasi oleh organisasi sejenis. BM juga secara tidak langsung menjadi landasan dalam melakukan penataan ulang terhadap sebuah organisasi termasuk menata ulang struktur organisasi dan reward systemnya. Merujuk pada penjelasan Pateli and Giaglis (2004) penyusunan BM UIS dilakukan dengan terlebih dahulu melihat kembali dua faktor utama yang biasanya menjadi dasar pertimbangan dalam memilih business model, yaitu (a) faktor internal, dalam hal ini lebih pada corporate identity dan core business UIS dan (b) faktor eksternal, dalam hal ini diartikan sebagai nilai tambah (value added) yang hendak ditawarkan kepada konsumen. Untuk itu, diperlukan analisis dan uraian terhadap kedua faktor pertimbangan tersebut di atas.

\section{Corporate identity (Visi, Misi dan Nilai- nilai Luhur) UIS}

Sebagai sebuah institusi pendidikan, UIS telah memiliki corporate identity; meski pernyataan resminya baru dibuat pada beberapa tahun belakangan. Dari pernyataan resmi corporate identity UIS serta hasil interpretasi ulang atas corporate identitiy tersebut, dapat dikatakan bahwa UIS bukan sekedar lembaga pendidikan semata yang hanya menyelenggarakan proses pendidikan, melainkan sebuah perguruan tinggi yang 
diharapkan bisa membekali para alumninya dengan keunggulan-keunggulan tertentu sehingga bisa bermanfaat bagi lingkungan baik dalam skala lokal, regional, nasional maupun internasional. Bagi UIS keunggulan dan nilai manfaat tersebut dianggap tidak ada artinya apa-apa jika para alumni tidak memiliki bekal dengan risalah Islamiah memiliki komitmen terhadap niali-nilai Islam.

Dari penjelasan tersebut dapat diartikan bahwa fokus perhatian UIS dalam menjalankan aktivitasnya dapat dikelompokan menjadi dua, yaitu menghasilkan produk/jasa, serta mempersiapkan manusia sebagai pelakunya (aktor). Dengan demikian, tidak saja output yang harus memenuhi berbagai syarat sebagaimana tersebut di atas, akan tetapi pada setiap proses bisnis di lingkungan UIS harus dilandasi oleh ketiga pilar tersebut, yaitu: (a) keunggulan/ kesempurnaan, (b) nilai manfaat, dan (c) risalah Islamiah. Ketiga pilar inilah yang diyakini berfungsi sebagai idiologi dasar (core ideology) UIS. Secara lebih rinci core ideology ini (lihat Collins and Porras, 1996) atau sering disebut juga guiding beliefs (Davis, 1984) dapat dipisahkan menjadi nilai dasar (core value) dan tujuan dasar (core purpose). Dalam hal ini, core value diperankan oleh nilai-nilai Islam; sementara core purpose diwujudkan sebagai tekad untuk mencapai keunggulan/ kesempurnaan yang bernilai manfaat. Secara keseluruhan, core ideology UIS adalah tekad untuk meraih keunggulan/kesepurnaan yang bernilai manfaat dengan berlandaskan pada nilai-nilai Islam. Tekad inilah yang kemudian akan mewarnai kerangka pikir dan setiap gerak-langkah (strategi) UIS dalam mewujudkan tujuan (misi), baik jangka pendek, menengah maupun tujuan jangka panjang. Pemahaman ini pada dasarnya merupakan reinterpretasi terhadap visi UIS. Gambar 5 menjelaskan konsep tersebut di atas. Sebagai catatan, paparan di atas lebih didasarkan pada dokumen visi UIS yang telah secara formal didokumentasikan. Sementara, kajian terhadap misi dan nilai-nilai luhur UIS belum secara eksplisit dilakukan. Hal ini disebabkan belum adanya rumusan formal berkait dengan kedua hal tersebut

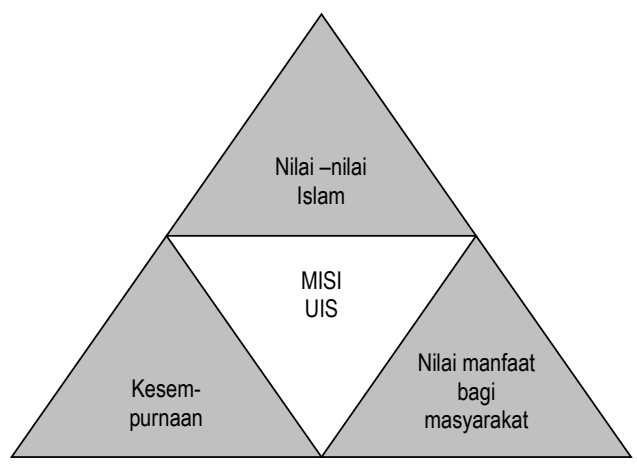

Gambar 5: Reinterpretasi Visi UIS

\section{Core Business UIS}

Komponen kedua yang akan dijadikan dasar perimbangan internal dalam menentukan business model adalah bisnis inti (core business) yang digeluti sebuah organisasi. Sebagaimana kita ketahui UIS adalah sebuah perguruan tinggi. Seperti layaknya perguruan tinggi yang lain, bisnis UIS berhubungan dengan ilmu pengetahuan (knowledge). Oleh karena itu, secara sederhana, produk/jasa utama yang dihasilkan UIS adalah ilmu pengetahuan. Selain itu, harus diakui pula bahwa selain produk/jasa utama tersebut, UIS juga menghasilkan produk/jasa sampingan. Dan sangat diharapkan, tentunya, bahwa produk/jasa sampingan tersebut berkait erat dengan produk utama serta mampu menjadi penunjang bagi keunggulan dan sustainability produk utama tersebut. Artinya bahwa pengembangan UIS ke depan, mestinya tidak melupakan core business utama (sekaligus sebagai core capability) UIS. Dengan kata lain, apapun jenis aktivitas sebagai bentuk pengem- 
bangan UIS ke depan sangat dimungkinkan sepanjang tidak keluar dari koridor core business tersebut.

\section{Nilai tambah (added values)}

Analisis faktor eksternal lebih difokuskan pada pembentukan nilai tambah (added value) yang berupa nilai manfaat yang dirasakan oleh konsumen (user). Hal ini sesuai dengan yang tersirat dan tersurat dalam visi UIS, yaitu rahmatan lil alamin. Oleh karena itu, diperlukan kajian yang mendalam atas user yang menjadi sasaran serta kebutuhan mereka yang hendak dipenuhi oleh UIS. Hal ini sekaligus mengindikasikan bahwa tidak dibenarkan bagi UIS memilih program/aktivitas yang tidak memberikan nilai kemanfaatan bagi user. Keberhasilan program UIS, salahsatunya, akan diukur sejauh mana program tersebut berkontribusi dalam mewujudkan nilai manfaat bagi masyarakat.

\section{Disain Business model UIS}

Berdasarkan pertimbangan internal (corporate identity dan core business UIS), serta pertimbangan eksternal, yakni nilai tambah yang ingin diberikan kepada konsumen (user), business model UIS dapat dijelaskan sebagai berikut.

Sebagaimana ditegaskan sebelumnya, bisnis utama UIS adalah produk/jasa ilmu pengetahuan yang memberikan nilai manfaat bagi konsumen (user). Meskipun demikian, perlu dirumuskan lebih jauh dan tegas: siapa sebenarnya konsumen UIS dan kebutuhan mereka yang mana yang hendak dipenuhi oleh UIS. Dengan kata lain, ilmu pengetahuan seperti apa yang ingin ditawarkan UIS kepada para konsumen yang mana. Untuk menjawab pertanyaan-pertanyaan tersebut, berikut ini akan disajikan mekanisme open system dalam proses pembentukan nilai tambah yang sekaligus merupakan business model UIS yang hendak ditawarkan (lihat gambar 6).

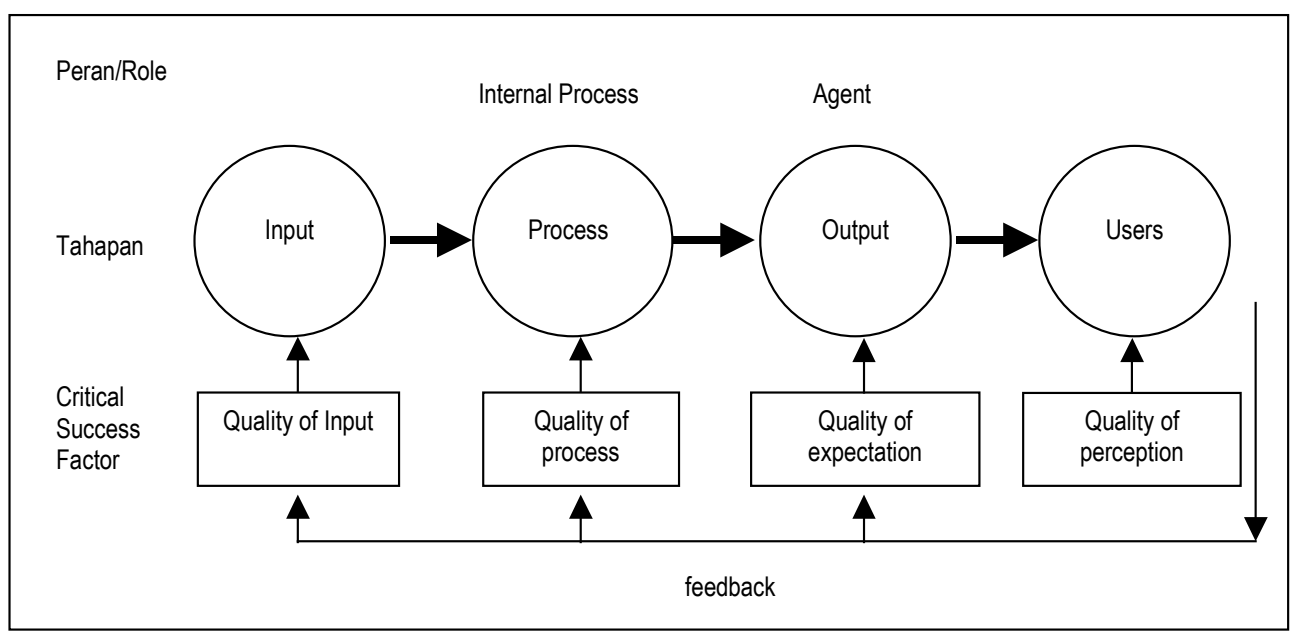

Gambar 6: Business model UIS 
Berdasarkan mekanisme business model di atas, berbagai macam input yang diperoleh dari lingkungan bisnis diolah dan ditransformasikan melalui proses aktivitas internal organisasi menjadi output yang bernilai tambah. Output inilah yang kemudian akan dimanfaatkan oleh para konsumen (users). Jika dikatakan bahwa produk utama UIS adalah ilmu pengetahuan (knowledge), maka berdasarkan mekanisme di atas yang merupakan output tidak lain adalah ilmu pengetahuan. Persoalan menjadi kritis manakala mendefinisikan siapa sebenarnya yang akan memanfaatkan output UIS.

Selama ini ada anggapan bahwa yang berkepentingan dengan ilmu pengetahuan yang dihasilkan oleh sebuah perguruan tinggi adalah mahasiswa dan orang tua mahasiswa. Sehingga, seolah-olah pengguna akhir (end user) output (ilmu pengetahuan) adalah para alumni perguruan tinggi tersebut. Dengan anggapan ini berarti tanggungjawab perguruan tinggi berakhir pada saat mahasiswa telah lulus sekaligus menyandang status baru sebagai alumni. Hal ini terbukti jika menyimak pidato rektor yang tidak jarang diperdengarkan pada saat acara wisuda, seperti: “...tugas saya sudah selesai dan saya kembalikan putra putri Bapak/Ibu. Selanjutnya bahwa putra putri Bapak/Ibu mau diapakan atau mau dikemanakan terserah Bapak/Ibu sendiri."

Harus diakui bahwa seorang mahasiswa yang belajar di perguruan tinggi berharap kelak "memperoleh ilmu pengetahuan serta menjadi lebih cerdas." Bagi seorang alumni, ilmu pengetahuan dan kecerdasan tersebut sesungguhnya akan dijadikan sebagai bekal untuk terjun ke masyarakat. Jika demikian, pada dasarnya ilmu pengetahuan dan kecerdasan seorang alumni tidak ada artinya apa-apa jika alumni tersebut tidak dapat diterima masyarakat. Hal ini menunjukan bahwa end users dari proses aktivitas yang dilakukan oleh sebuah perguruan tinggi sesungguhnya adalah masyarakat, bukan sekedar alumni dan orang tuanya. Kalaulah para alumni juga memperoleh manfaat dari sebuah perguruan tinggi, maka manfaat tersebut barulah sekedar potential benefit sampai, nantinya, betul-betul terealisir pada saat yang bersangkutan terjun ke masyarakat dan masyarakat memperoleh benefit dari keterlibatan alumni tersebut. Untuk itu seorang alumni mestinya bukan sekedar cerdas, tetapi cerdas secara mental, moral intelektual dan sosial.

Jika penjelasan di atas diterjemahkan dari perspektif sebuah perguruan tinggi, dalam hal ini UIS, maka para alumni lebih tepat diperlakukan bukan sebagai end users melainkan sebagai intermediary, channel of distribution, agent atau dealer (Holbrook and. Hulbert, 2002) yang memasarkan ilmu pengetahuan hasil olahan UIS ke masyarakat. Atau dengan kata lain alumni adalah jembatan (bridge) dan sekaligus liaison antara pihak internal (UIS) dengan pihak eksternal (masyarakat sebagai end users). Harus diakui bahwa konsep ini telah disadari dan dipahami oleh banyak perguruan tinggi, khususnya perguruan tinggi besar dan bahkan Dikti sekalipun. Namun formulasi secara eksplisit tampaknya belum pernah dilakukan oleh perguruan tinggi lain. Oleh karena itu, tepat kiranya jika konsep business model ini diimplementasikan oleh UIS. Dalam bentuk jargon, business model UIS bisa dinyatakan dalam sebuah kalimat:

\section{"menjadikan alumni UIS sebagai 'agent' untuk membangun masyarakat yang bermartabat - crafting agent to enhance human dignity”}

\section{Implikasi Dari Business model UIS}

Berasumsi bahwa business model UIS adalah sebagaimana disebutkan di atas, maka perlu disadari adanya beberapa implikasi yang harus dijalankan oleh UIS. Harus disadari pula bahwa implikasi tersebut bukan implikasi ringan, sebaliknya 
merupakan implikasi berat. Pelaksanaannya membutuhkan perubahan arsitektur organisasi secara menyeluruh. Berikut adalah beberapa implikasi yang perlu mendapat perhatian serius dari manajemen UIS berikut:

1. Kemampuan dan keahlian. Jika para alumni diperlakukan sebagai agent atau channel of distribution, maka yang dibutuhkan oleh alumni bukan hanya sekedar ilmu pengetahuan yang akan mereka pasarkan, akan tetapi juga persyaratan-persyaratan sebagai seorang agen. Artinya selama proses pembelajaran di UIS, mahasiswa harus memperoleh dua hal. Pertama adalah ilmu pengetahuannya itu sendiri dan kedua adalah character dan skill sebagai seorang agen. Inilah tanggungjawab besar yang harus dijalankan UIS melalui seluruh proses internal yang ada, dengan, secara optimal, melibatkan berbagai sumberdaya dan rantai nilai serta sarana dan prasarana yang tersedia sebagai faktor pendukung.

Mengingat bahwa proses pembentukan karakter dan skill, sebagai modal dasar menjadi seorang agen, memerlukan waktu yang relatif lama, maka sebagai konsekuensi logis, model bisnis ini tidak memberikan wadah bagi programprogram yang berdurasi pendek (program instant), kecuali programprogram pendukung pembentukan karakter dan skill tersebut.

2. Kurikulum. Mengingat end-users yang sesungguhnya adalah masyarakat, kurikulum sudah seharusnya didesain agar dapat memenuhi kebutuhan mereka. Oleh karena itu, kurikulum harus bersifat dinamis yang sekaligus diarahkan untuk menciptakan keunggulan. Di sisi lain, kebutuhan akan pembekalan bagi alumni, yang memiliki peran sebagai seorang agent, dengan bekal karakter dan skill menuntut adanya kecermatan dalam mendesain kurikulum, terutama kurikulum Universitas. Karakter yang akan diberikan pada alumni merupakan karakter khas UIS, yaitu nilai-nilai Islam. Oleh karena itu, proses dan model pembelajaran matakuliah (agama) harus mendapatkan prioritas serius. Dengan demikian, kesan pembalajaran matakuliah agama yang lebih bertumpu pada transfer knowledge lebih diarahkan untuk memberikan bekal alumni kemampuan untuk survive (survival skill) berdasar nilai-nilai Islam. Inilah yang diharapkan mampu menjadi keunggulan ke-agent-an alumni UIS. Mereka tidak saja unggul dalam ilmu pengetahuan, akan tetapi juga mulia dalam karakter.

3. Pola seleksi calon mahasiswa. Business model UIS yang diusulkan mengindikasikan hal yang sangat berbeda terhadap perlakuan terhadap output. Pada business model yang baru, keberhasilan UIS diukur sejauh mana alumni mampu terserap dalam lapangan kerja dan sekaligus mampu mengintrodusir UIS secara positip. Dengan kata lain, alumni yang tidak sempat berkiprah secara langsung di tengah masyarakat, di mata UIS, relatif memiliki nilai keberhasilan yang rendah, karena peran mereka sebagai agen menjadi tidak berlangsung. Tidak dipungkiri bahwa kebanyakan dari mereka adalah wanita. Meskipun disadari bahwa fungsi keagenan mereka sangat boleh jadi dijalankan bagi keturunan mereka. Sehingga dalam jangka waktu yang relatif panjang, mereka tetap juga berkontribusi terhadap UIS melalui peran keagenannya.

Mengingat hal tersebut, untuk kepentingan jangka panjang, UIS sudah semestinya lebih memprioritaskan calon mahasiswa pria. Namun demikian, untuk masa beberapa tahun ke depan 
(transisi), calon agen wanita masih penting untuk diprioritaskan. Paling tidak, dari pengalaman menunjukan bahwa wanita lebih tekun dalam mengikuti proses belajar sehingga prosentase keberhasilannya lebih tinggi dibanding pria. Selama masa transisi ini diharapkan UIS menyiapkan berbagai sistem/model serta kegiatan pendukung lainnya untuk menciptakan lingkungan yang kondusif bagi pertumbuhan dan perkembangan peran ke-agenan alumni UIS. Disamping itu, sejak awal, perlu dipertimbangkan agar pola rekruitmen seorang calon agen (calon mahasiswa) bukan hanya didasarkan pada test potensi akademik tetapi juga test character dan skill. Oleh karenanya sangat disarankan agar test dilakukan melalui dua tahap, yakni tahap pertama test character dan skill, dan jika lulus, barulah diperkenankan mengikuti test tahap kedua - TPA.

4. Manajemen Pasca Panen (post-sale services). Sebagaimana pada bahasan sebelumnya, model bisnis yang baru, menyebutkan bahwa tugas UIS tidak berhenti pada saat mahasiswa menyelesaikan studinya. Justru, tugas besar lain yang akan berlangsung dengan periode 'tak terbatas' mulai pasca wisuda. Peran mereka sebagai agen UIS perlu mendapat bantuan dan dukungan serta pengelolaan yang profesional. Upaya untuk mengikat mereka secara emosional harus dijalankan. Sehingga pada saat UIS mengundang mereka, dan ini harus terprogam dengan baik, mereka ada keterikatan untuk datang. Kondisi inilah yang kemudian harus 'dimanfaatkan' secara win-win elegant program untuk men-generate income dari peran mereka sebagai agen.

5. Pola Manajemen. Business model yang baru dengan implikasi yang cukup besar dan serius memberikan arahan yang jelas bagi manajemen tentang apa yang harus dilakukan. Kepastian atas kesesuaian antara kurikulum dengan keinginan masyarakat serta lingkungan kondusif bagi kemampuan tumbuh dan berkembangnya fungsi keagenan alumni, menjadi tugas pokok yang harus mendapatkan perhatian utama. Tugas-tugas ini akan sangat terjamin keberhasilannya dengan pola: (a) tanggungjawab untuk mengetahui keinginan masyarakat melalui berbagai model dan kegiatan riset pasar diberikan kepada rektor dan dekan; (b) desain kurikulum dan model pembelajaran dengan mengacu pada temuan yang diperoleh rektor dan dekan, secara penuh diserahkan pada program studi; (c) penyiapan kondisi bagi kemampuan tumbuh dan berkembanganya peran keagenan dilakukan oleh rektor melalui berbagai bentuk pembentukan jejaring (networking) dengan end-users.

6. Strategi Korporat (corporate strategy). Tidak terelakan, model bisnis UIS ini membutuhkan kejelasan strategi. Kejelasan tidak saja pada statemen, tapi juga kejelasan dalam tahapan strategi yang harus dijalankan. Rancangan strategi yang seharusnya menjadi pilihan adalah collaborating, competing, leading dan achieving standard of excellence. Kolaborasi menjadi pilihan strategi pada tahap awal. Tujuan srategi ini tidak lain dimaksudkan untuk membangun pondasi bagi kelancaran strategi-strategi berikutnya, serta sekaligus sebagai kunci sukses bagi pengembangan ilmu pengetahuan dan fungsi keagenan. Tahap kedua, competing. Bermodal jejaring yang kuat diharapkan UIS memiliki kemampuan untuk berkompetisi. Tahap ketiga, leading, UIS berupaya kuat untuk tidak saja berkompetisi, tapi sekaligus memimpin. Acieving standard of excel- 
lence, sebagai strategi tahapan terakhir, menjadi satu keniscayaan akibat dari implementasi strategi pada tahapantahapan sebelumnya.

7. Struktur Organisasi. Model bisnis UIS yang baru secara serius membutuhkan kecepatan dalam merespon dinamika perubahan lingkungan eksternal. Dengan demikian diperlukan bentuk organisasi dengan struktur yang sangat ramping sebagai jaminan terciptanya kecepatan dalam pembuatan keputusan. Sangat boleh jadi, hal ini berimplikasi pada perlunya peninjauan ulang model hubungan antara Yayasan dan Universitas sebagaimana yang selama ini ada. Tinjauan lebih diarahkan pada upaya menghindari adanya tumpah-tindih (overlap) kegiatan yang berdampak pada semakin panjangnya jalur birokrasi.

Pada sisi yang lain, model bisnis ini menuntut pula pemberian kewenangan penuh kepada program studi untuk mempersiapkan kurikulum (bidang akademik) yang dibutuhkan masyarakat. Disamping itu, model bisnis ini membutuhkan pula peran CEO di tingkat universitas maupun di tingkat fakultas sebagai pembuat keputusankeputusan yang bersifat strategik. Oleh karena itu, bentuk 2 (dua) layers menjadi pilihan. Keberhasilan bentuk struktur organisasi ini akan sangat tergantung pada tersedianya dukungan optimalisasi peran teknologi informasi dan sistem pendukung (supporting system) lainnya.

8. Reward system. Dengan business model UIS yang baru, yang menuntut kerja keras dan komitmen dosen dan karyawan, tidak terelakkan menuntut perubahan reward system. Jika selama ini dosen dan karyawan menerima gaji dari UIS semata-mata karena bekerja di UIS maka pola semacam ini tampaknya tidak bisa diberlakukan lagi. Sekarang dosen dan karyawan UIS harus menempatkan diri sebagai orang yang bekerja untuk UIS dengan satu konsekuensi memenuhi semua standard yang berlaku di UIS termasuk menjaga risalah Islamiah, unggul dan memiliki nilai manfaat. Implikasinya sudah selayaknya UIS dalam memberikan reward juga berdasarkan ukuran standard tersebut. Dengan demikian, paling tidak ada dua basis yang bisa dijadikan ukuran reward yakni etika dan ability.

\section{DISKUSI HASIL DAN SIMPULAN}

Perubahan lingkungan organisasi, diantaranya ditandai oleh perubahan teknologi yang begitu cepat (yakni munculnya teknologi informasi dan komunikasi ICT) direspon para praktisi bisnis dengan merubah paradigma atau mental model dalam menjalankan bisnis dan mengelola organisasi. Dewasa ini misalnya istilah click-and-mortar-business banyak digunakan untuk mengganti brick-and-mortarbusiness. Migrasi ke e business model ini (Weill and Vitale, 2001) terjadi karena peluang yang begitu terbuka untuk menjalankan bisnis berbasis ICT. Meski demikian peluang ini akan menjadi sia-sia jika tidak barengi perubahan paradigma dalam menjalankan bisnis. Hal ini terbukti misalnya banyak bisnis berbasis ICT yang mengalami kegagalan karena masih menggunakan business model lama (Vickers, 2000).

Dibandingkan para pelaku bisnis, para akademisi tampaknya sedikit lebih lambat dalam merespon perubahan lingkungan tersebut. Ketika para praktisi bisnis sudah selangkah lebih maju dalam membangun business model baru, para akademisi masih memperdebatkan urgensi membangun konsep BM (Porter, 2001). Meski perdebatan tersebut mulai menurun, muncul persoalan baru yang sampai kini belum tuntas - yakni belum adanya kesepakatan 
tentang konsep BM. Akibatnya masih terdapat dua kubu yang berbeda, khususnya mengenai kedudukan BM dalam konteks arsitektur organisasi secara keseluruhan. Kubu pertama memandang bahwa BM merupakan abstraksi dari strategi bisnis. Pandangan ini cenderung dianut oleh para akademisi berlatarbelakang manajemen. Sedangkan kubu kedua sebaliknya beranggapan bahwa strategi merupakan abstraksi dari BM yang cenderung dianut para akademi berlatarbelakang teknologi informasi. Jika kubu pertama melihat BM sebagai komponen organisasi yang bersifat abstrak, kubu kedua melihat sebaliknya BM bersifat detail.

Terlepas dari masih muncul perdebatan tentang konsep BM, penulis meyakini bahwa membangun dan memiliki BM yang unik dan tidak mudah diimitasi organisasi lain tampaknya sudah menjadi keharusan jika sebuah organisasi atau perusahaan menghendaki organisasi perusahaan yang dikelola survive dan berkembang dalam lingkungan yang serba berubah. Demikian juga seperti halnya akademisi berlatarbelakang manajemen lainnya, penulis berpihak pada kubu pertama. Dengan demikian kasus UIS dalam paper menggunakan asumsi-asumsi ini.

Hasil studi penyusunan BM UIS yang menggunakan pendekatan action research (mengikuti pola yang digunakan Petrovic et al., 2001 dan Auer and Follack, 2002) menunjukkan bahwa merubah BM bagi organisasi yang telah lama eksis bukan pekerjaan mudah. Boleh jadi sulitnya merubah BM ini karena pada umumnya perguruan tinggi lebih bernuansa administratif (Robertson, 1984) yang cenderung resisten terhadap perubahan. Disamping itu perubahannya itu sendiri tidak memberi dampak yang instan terhadap kinerja organisasi. Sebaliknya, seperti ditunjukkan oleh kasus UIS, perubahan BM justru harus diikuti oleh perubahan-perubahan yang tidak ringan bagi manajemen organisasi. tanpa ada perubahanperubahan ini diyakini bahwa merubah BM seperti yang diyakini Porter (2001) tidak akan merubah apa-apa.

\section{REFERENSI}

Abrahamson, E. (1996). Management Fashion, Academy of Management Review, 21 (1), pp. 254-285.

Alt, R. and H. Zimmermann. (2001). Preface: Introduction to Special Section - Business Models, Journal of electronic markets, 11 (1), pp.3-9.

Amit, R. and C. Zott. (2001). Value Creation in e-Business, Strategic management journal, $22(6 / 7)$, pp. 493-520.

Auer, C. and C. Follack. (2002). Using Action Research for Gaining Competitive Advantage out of The Internet's Impact on Existing Business Model, Proceeding of $15^{\text {th }}$ Bled Electronic Commerce Conference - eReality: Constructing the eEconomy, Bled, Slovenia.

Bahner, R.R. and L.K. Stroh. (2004). The Transformation Management Model: A Tool Evaluation Route to Business Change Success, Problems and Perspectives in Management, 4, pp. 180-191.

Barabba, V.et.al. (2002). A Multimethod Approach for Creating New Business Models: The General Motors OnStar project, Interface, 32 (1), pp. 20-24. 
Betz, F. (2002). Strategic Business Models, Engineering Management Journal, 14, 1, pp. 2127.

Bouwman, H. (2003). State of The Art on Business Model, Telematica Instituut, TU Delft.

Cameron, K.S. (1984). Organizational Adaptation and Higher Education, Journal of higher education, vol. 55, no.2, pp.122-144.

Carlson, P.M and M.S. Fleisher. (2002). Shifting Realities in Higher Education: Today's Business Model Threatens Our Academic Excellence, International Journal of Public Administration, Vol. 25, No. 9\&10, pp. 1097-1111.

Chabarbaghi, K., C. Fendt and R. Willis. (2003). Meaning, Legitimacy and Impact of Business Models in Fast-Moving Environment, Management Decision, Vol. 41, No. 4, pp. 372-382.

Chesbrough, H. And R.S. Rosenbloom. (2002). The Role of Business Model in Capturing Value from Innovation: Evidence from Xerox Corporation's Technology Spin-off Company, Industrial and Corporate Change, Vol. 11, No. 3, pp. 529-555.

Chesbrough, H., S. Ahern, M. Fenn and S. Guerraz. (2006). Business Models for Technology in The Developing World: The Role of Non-Governmental Organizations, California Management Review, Vol.48, No. 3, pp. 48-61.

Chesbrough, H. and K. Schwartz. (2007). Innovating Business Models with Co-Development Partenership, Research-Technology Management, January-February, pp. 55-59.

Collins, J. C. and J. I. Porras. (1996). Built to Last, London, U. K. Century business.

Davis, S. (1984). Managing Corporate Culture, Reading MA: Addison-Wesley.

Dick, B. (2002). Action Research: Action and Research, Available at: http://www.scu.edu.au/schools/gcm/ar/arp/aandr.html diakses 25/11/2007.

Gordijn, J., A. Osterwalder and Y. Pigneur. (2005). Comparing Two Business Model Ontologies for Designing E-Business Model and Value Constellations, Proceeding of 18 th e-conference e-integration in action, Bled, Slovenia.

Gulati, R. and D. Kletter. (2005). Shrinking Core, Expanding Periphery: The Relational Architecture of High-Performing Organizations, California Management Review, Vol. 47, No. 3, pp. 77-104.

Hedman, J. and T. Kalling. (2003). The Business Model Concept: Theoritical Underpinnings and Empirical Illustrations, European Journal of Information Systems, 12, pp.49-59.

Holbrook, M. B. and J. M. Hulbert. (2002). What do We Produce in the "Knowledge Factory" and for Whom? A Review Essay of The Knowledge Factory by Stanley Aronowitz, Journal of consumer affairs, 36/1, pp. 99-114.

Keen, P. and S. Qureshi. (2006). Organizational Transformation Through Business Models: A framework for Business Model Design, Proceeding of the 39th Hawaii International Conference on Sstem Science, Hawaii. 
SIIERGI Vol. 9 No. 2, JUNI 2007: 103 - 128

Keidel, R.W. (1984). Baseball, Footbal and Basketball: Models for business, Organizational dynamics, pp. 5-17.

Kraemer, K.L., J. Dedrick and S. Yamashiro. (2000). Refining and Extending the Business Model with Information Technology: Dell Computer Corporation, The Infomation Society, 16, pp. 5-21.

Lambert, S. (2003a). A Review of Electronic Commerce Literature to Determine The Meaning of The Term "Business Model", School Of Commerce Research Paper Series: $03-5$, Flinders University of South Australia available at http://www.flinder.edu.au/

Lambert, S. (2003b). Making Sense of Business Models, School of Commerce Research Paper Series: 03 - 10, Flinders University of South Australia available at http://www.flinder.edu.au/

Lambert, S. (2006a). Do we need a real taxonomy of e-business models? http://www.flinders.edu.au/

Lambert, S. 2006b, A Business Model Research Schema, Paper Presented at $19^{\text {th }}$ Bled eConference on eValue, Bled, Slovenia, June 5-7, 2006.

Linder, J.C and S. Cantrell. (2000). Changing Business Models: Surveying the Landscape, Working Paper, Accenture - Institute for Strategic Change.

Linder, J.C and S. Cantrell. (2001). Five Business Model Myth that Hold Company Back, Strategy \& Leadership, 29, 6, pp. 13-18.

Lissack, M.R. and K.A. Richardson. (2003). Models Without Morals: Toward the Ethical Use of Business Models, Emergence, 5 (2), pp. 72-102.

Looney, C.A, L.M. Jessup and J.S. Valacich. (2004). Emerging Business Models for Mobile Brokerage Service, Communication of the ACM, Vol. 47. No. 6, pp. 71-77

Magretta, J. (2002). Why Business Models Matter, Harvard Business Review, May, pp.86-92.

Magretta, J. (1998). The power of virtual integration: Interview with Dell Computer's Michael Dell, Harvard Business Review, March-April, pp.73-84.

Mahadevan, B. (2000). Business Models for Internet-Based e-Commerce, California Management Review, 42 (4), pp. 55-69.

Mansfield, G.M., L.C.H. Fourie and W.R. Gevers. (2005). Strategic Archietecture as a Concept Towards Explaining The Variation In Performance of Networked Era Firms, South Africa journal of business management, 36 (4), pp. 19-31.

Osterwalder, A. (2004). The Business Model Ontology - A Proposition in a Design Science Approach, Unpublished dissertation, Universite De Lausane Ecole Des Hautes Etudes Commerciales, available at: http://www.hec.uni/ch/osterwalder

Osterwalder, A. and Y. Pigneur. (2002). An ebusiness model ontology for modeling eBusiness, Proceeding of 15thBled electronic commerce conference - eReality: Constructing the eEconomy, Bled, Slovenia. 
Osterwalder, A., Y. Pigneur and C. L. Tucci. (2005). Clarifying Business Models: Origins, Present and Future of the Concept, Communications of the Association for Information Systems, Vol. 16, pp. 1-25.

Owens, J.D. (2006). Electronic Business: A Business Model can Make difference, Management services, pp. 24-28.

Pateli, A.G. and G.M. Giaglis. (2002). A Domain Area Report on Business Models, White paper: ELTRUN - Athens University of Economics and Business, Greece.

Pateli, A.G. and G.M. Giaglis. (2004). A research framework for analyzing eBusiness models, European Journal of information systems, 13 (4), pp. 302-314.

Petrovic, O., C. Kittl and R.D. Teksten. (2001). Developing Business Models for eBusiness, Proceedings of the International Conference on Electronic Commerce 2001, Vienna, Austria, October 31 - November 4.

Porter, M.E. (1996). What is Strategy? Harvard business review, pp. 61-78.

Porter, M.E. (2001). Strategy and the Internet, Harvard business review, pp. 63-78.

Rappa, M.A. (2004). The utility of Business Model And The Future Of Computing Services, IBM systems journal, 43 (1), pp. 32-42.

Rappa, M.A. (2007). Managing the digital enterprise - Business Models on the web, http://digitalenterprise.org/models/models.html

Richers and Schneider. (1990). Climate and Culture: An Evaluation of Construct, In Scheider (ed.) Organizational Climate and Culture, Jossey Bass Publisher.

Robertson, D. (1993). Establishing Strategic Direction In Higher Education Institutions, Public Money \& management, July-September, pp.45-51.

Seddon, P.B., G.P. Lewis, P. Freeman and G. Shanks. (2004). The Case for Viewing Business Models as Abstractions Of Strategy, Communications of the Association for Information Systems, vol. 13, pp. 427-442.

Smith, R. (2002). The Role of University Head of Department, Education Management \& Administration, 30/3, pp. 293-312.

Schweizer, L. (2005). Concept and Evolution Of Business Models, Journal Of General Management, 31 (2), Pp. 37-56.

Timmers, P. (1998). Business model for electronic markets, Journal on electronic markets, 8 (2), pp. 3-8.

Vickers, M. (2000). Model from Mars, Business week, 4 September, pp. 58-59.

Voelpel, S.V., M. Leibold and E.B. Tekie. (2004). The Wheel Of Business Model Reinvention: How to reshape your business model to leapfrog compettitors, Journal of Change Management, 4, 3, pp. 259-276.

Weill, P and M.R. Vitale. (2001). Place to Space: Migrating to eBusiness Models, Boston: MA, Harvard Business School Press. 
SIIERGI Vol. 9 No. 2, JUNI 2007: 103 - 128

Weill, P., T.W. Malone, V.T. D'Usro, G. Herman and S. Woerner. (2005). Do Some Business Models Perform Better Than Others? A Study of the 1000 Largest US Firms, Working Paper, Sloan School of Management, Massachussets Institute of Technology. 